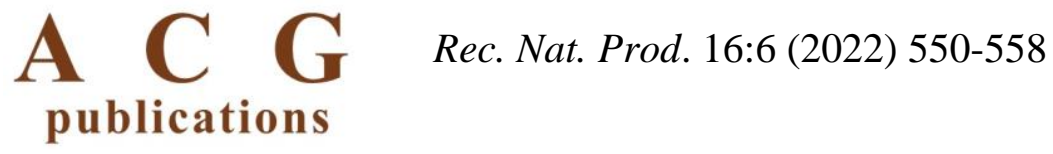

records of natural products

\title{
Triterpenes and Saponins from Leaves of Camellia nitidissima, and Cytotoxic Activities Against Bel-7402 and SMMC-7721 Human Liver Cancer Cells
}

\author{
Yanan Xu ${ }^{1}$, Siyuan Ma ${ }^{1}$, Xiaofang Han ${ }^{2}{ }^{2}$, Lin Su ${ }^{3}$, Li Ge ${ }^{2 *}$, \\ Qiuhong Chen ${ }^{3}$, Kedi Yang ${ }^{2 *}$ and Qifei Mo ${ }^{4}{ }^{4}$ \\ ${ }^{1}$ School of Chemistry \& Chemical Engineering, Guangxi University, Nanning, Guangxi 530004,China \\ ${ }^{2}$ Medical College, Guangxi University, Nanning, Guangxi 530004, China \\ ${ }^{3}$ Guangxi Research Center of Analysis and Testing, Guangxi 530022, China \\ ${ }^{4}$ Centre Testing International (Guangxi) Corporation, Guangxi 530100, China
}

(Received November 25, 2021; Revised February 06, 2022; Accepted February 09, 2022)

\begin{abstract}
Camellia nitidissima is commonly used for making tea to prevent cancer in China, but its phytochemicals and bioactivity was insufficiently reported. In this work, the total content of saponins from leaves of $C$. nitidissima was investigated, and the high level of total saponins varied obviously with the augment of leafage. There are 12 triterpenes and saponins, i.e., $\beta$-daucosterol (1), $\alpha$-spinasterol- $\beta$-D-glucoside (2), lupeol

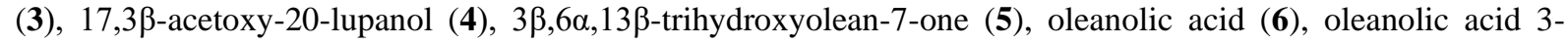
acetate (7), ginsenoside $\operatorname{Rg}_{1}(\mathbf{8})$, ginsenoside $F_{5}(\mathbf{9})$, ginsenoside $F_{1}(\mathbf{1 0})$, ginsenoside $\operatorname{Rd}(\mathbf{1 1})$, and $(3 \beta, 6 \alpha, 12 \beta)$ 3,6,12-trihydroxydammar-24-en-20-yl-2-O- $\beta$-D-glucopyranosyl-(2 $\rightarrow 1)-\mathrm{O}-\beta$-D-glucopyranosyl- $(2 \rightarrow 1)-\mathrm{O}-\alpha$-Lrhamnopyranoside (12) from $C$. nitidissima leaves were isolated and identified. Specially, five dammarane tetracyclic triterpenoids derived from 20(S)-protopanaxatriols (compounds 8-12) obtained from C. nitidissima were the first reported, and compound $\mathbf{1 2}$ is a new dammarane triterpenoid. Based on scratch assay and cell counting kit-8 (CCK-8) assay, compound 12 and the extracts of $C$. nitidissima leaves showed potential cytotoxic activities against Bel-7402 and SMMC-7721 human liver cancer cells in vitro.
\end{abstract}

Keywords: Camellia nitidissima; triterpenes and saponins; cytotoxic activities; liver cancer. (C) 2022 ACG Publications. All rights reserved.

\section{Introduction}

Yellow Camellia, is also known as Golden Camellia, and belongs to the Theaceae family that comprise approximately 42 species and 5 variants. Camellia nitidissima is one of the most well-known species of yellow Camellia with golden flowers, and its leaves and flowers have been used to make tea, as well as folk medicines to treat hypertension, sore throat and prevent cancer, and they have been

\footnotetext{
* Corresponding author: E-Mail: geli_2009@gxu.edu.cn (Li Ge), kdyang@163.com (Kedi Yang); Phone:08615078778659 (Li Ge), 086-18376765663 (Kedi Yang) 
recognized as new food sources by the State Food \& Drug Administration of China in 2010. Though C. nitidissima is rare and endemic to a narrow region of Guangxi province in Southern China and Northern Vietnam, it has been widely cultivated due to high economic value and potential as tea and functional food sources since 2010. However, there is insufficient information about its biological activities and phytochemicals.

During these years, interesting biological activities of the yellow Camellia have been reported, including anticancer activity [1-4], antioxidant activity [5,6], and inhibiting the formation of advanced glycation end-products[7,8], which may relate to their chemical components of yellow Camellia, such as flavonoids, triterpenoids and polyphenols etc. The chemical constituents from $C$. nitidissima have been partially analyzed and identified so far [9-14], but the information about its compositions and biological activities is still inadequate. In this study, we measured the total content of saponins in $C$. nitidissima leaves with different leafage, and obtained twelve triterpenes and saponins from $C$. nitidissima. It is interesting that five dammarane tetracyclic triterpenoids derived from $20(S)$ protopanaxatriols were isolated from $C$. nitidissima for the first time, and a new dammarane triterpenoid (compound 12) has not been reported before. In addition, we evaluated the cytotoxic activitie of the extracts of $C$. nitidissima and the new compound 12 against Bel-7402 and SMMC-7721 human liver cancer cells.

\section{Materials and Methods}

\subsection{Plant Material}

Leaves of Camellia nitidissima with different leafage were picked from a group of trees and pooled together in 2016 from Fangcheng Yellow Camellia National Natural Reserve in Guangxi Province, China. This plant was identified by Professor Mouxiang Lai from Guangxi University of Chinese medicine, and a herbarium specimen of C. nitidissima (JHC2016010801) was deposited at the Guangxi Institute of Botany, Chinese Academy of Sciences. Human liver tumor cell lines of Bel-7402 and SMMC-7721 were purchased from Shanghai Institutes for Biological Sciences, Chinese Academy of Sciences.

\subsection{General}

${ }^{1} \mathrm{H}-\mathrm{NMR}$ and ${ }^{13} \mathrm{C}-\mathrm{NMR}$ spectra data were recorded on a Bruker AVANCE III HD $600 \mathrm{MHz}$ spectrometer with tetramethylsilane (TMS) as the internal standard. A Gilson GX-281 preparative HPLC equipped with a UV/Vis-156 detector was employed for the separation and purification of chemical constituents of $C$. nitidissima. The other instruments used for cytotoxic activity assay included a Thermo Forma $\mathrm{CO}_{2}$ incubator, a Nikon Eclipse Ti inverted microscope, a Dynex Spectra MR microplate reader and a clean bench. Cell Counting Kit-8 (CCK-8) was purchased from Nan Jing Tong Ren Chemical Research Institute (Nanjing, Jiangsu Province, China). Except for chromatographically pure acetonitrile, all the chemicals used were analytical grade.

\subsection{Extraction and Isolation}

The fresh leaves of $C$. nitidissima (one-year-old, $20 \mathrm{~kg}$ ) were air-dried in the shade for approximately two weeks, and then grounded into powder. These plant materials were extracted three times with $95 \%$ ethanol $(3 \times 20 \mathrm{~L}, 2 \mathrm{~h}$ each time) under reflux. The combined ethanol extracts were evaporated under reduced pressure to yield a dark green residue, and then suspended in water $(1 \mathrm{~L})$ to remove chlorophyll by using petroleum ether extraction $(3 \times 1 \mathrm{~L})$, following extraction with n-butyl alcohol twice $(2 \times 1 \mathrm{~L})$ to obtain n-butyl alcohol extract. An adsorption column packed with Diaion HP20 macroporous resin was performed to isolate the n-butyl alcohol extracts, and traced by $0.5 \%$ anisaldehyde-sulphuric acid chromogenic agent to obtain fractions by eluting with $60 \%$ and $95 \%$ ethanol, respectively. Then five fractions (A-E) were collected. $1.58 \mathrm{~g}$ of Fraction $\mathbf{E}$ was taken for further separation, after purification on repeated column chromatography via silica gel, afforded seven triterpenes (62 $\mathrm{mg}$ of $\mathbf{1}, 23 \mathrm{mg}$ of $\mathbf{2}, 18 \mathrm{mg}$ of $\mathbf{3}, 15 \mathrm{mg}$ of $\mathbf{4}, 11 \mathrm{mg}$ of $\mathbf{5}, 44 \mathrm{mg}$ of $\mathbf{6}$ and $32 \mathrm{mg}$ of 7). 


\section{Triterpenes and saponins from leaves of Camellia nitidissima}

Fraction $\mathbf{C}(833 \mathrm{mg})$ was subjected to preparative HPLC on a Phenomenex $\mathrm{C}_{18}$ column $(250 \times 21.20$ $\mathrm{mm}, 5 \mu \mathrm{m}$ ) at wavelength of $203 \mathrm{~nm}$, using a mixture of acetonitrile (A) and water (B) as mobile phase in a gradient system $(25 \% \mathrm{~A}$ at $0-5 \mathrm{~min}, 40 \% \mathrm{~A}$ at $5-35 \mathrm{~min}, 50 \% \mathrm{~A}$ at $35-60 \mathrm{~min}$ ), and successively obtained a mixture and three saponins (16 mg of $\mathbf{9}, 28 \mathrm{mg}$ of $\mathbf{1 0}, 25 \mathrm{mg}$ of 11), and the mixture was separated by repeated preparative HPLC to afford $32 \mathrm{mg}$ of 8 and $27 \mathrm{mg}$ of $\mathbf{1 2}$. There are seven triterpenes and five saponins were isolated from the leaves of $C$. nitidissima.

\subsection{Determination of Total Saponins in Leaves of C. nitidissima}

The total content of saponins in leaves of $C$. nitidissima was measured using a coloration method proposed by Baccou [15]. Briefly, $5 \mathrm{~g}$ of plant materials were reflux extracted for $6 \mathrm{~h}$ by using a Soxhlet extractor with $150 \mathrm{~mL}$ ethyl acetate, then the solution was concentrated to $20 \mathrm{~mL} .2 \mathrm{~mL}$ of the concentrated solution was reacted for 20 min using $1 \mathrm{~mL}$ of $0.5 \%$ anisaldehyde solution in ethyl acetate and $1 \mathrm{~mL}$ of concentrated sulphuric acid at $60^{\circ} \mathrm{C}$ in the test-tube, and then cooled for $10 \mathrm{~min}$ to room temperature in a water-bath. The absorbance of this reaction solution was measured at $430 \mathrm{~nm}$. The calibration curves were established by using oleanolic acid as a standard.

\subsection{Cell Culture and Scratch Assay}

Bel-7402 and SMMC-7721 cells were maintained in high glucose DMEM (Gibco, USA) that supplemented with 10\% FBS (Gibco, USA), $100 \mathrm{U} / \mathrm{mL}$ penicillin and $100 \mu \mathrm{g} / \mathrm{mL}$ streptomycin. All cells were incubated at $37^{\circ} \mathrm{C}$ in a humidified atmosphere containing $5 \% \mathrm{CO}_{2}$. The spreading and migration of these cells were assessed in vitro using a scratch wound assay [16]. The cells were seeded at $2.5 \times 10^{4}$ cells /well in 96-well plates in 10\% FBS-supplemented DMEM and incubated for $24 \mathrm{~h}$ to nearly confluent cell monolayers. Then, a linear wound was created in the monolayer by drawing with a sterile $100 \mu \mathrm{L}$ plastic pipette tip. The wounded monolayers were washed twice to remove cellular debris using phosphate buffer saline (PBS). 1\% FBS-supplemented DMEM containing the samples (0$200 \mu \mathrm{g} / \mathrm{mL}$ ) was added and incubated for $0,24 \mathrm{~h}$ and $48 \mathrm{~h}$ at the conditions described above. Then, the cells were photographed for migration assessment.

\subsection{Cell Proliferation and Cytotoxicity Assay}

Cell viability on Bel-7402 and SMMC-7721 cells were measured using CCK-8 assay. The cells were dispensed in 96-well plates at a concentration of $8 \times 10^{3}$ cells/well. After overnight incubation, they were treated with various concentrations of samples and incubated for $24 \mathrm{~h}, 48 \mathrm{~h}$ at $37{ }^{\circ} \mathrm{C}$. Two hours before the end of incubation, $20 \mu \mathrm{L}$ of CCK- 8 was added to each well. The cell inhibition rate was calculated according to the absorbance value at $590 \mathrm{~nm}$ measured using a microplate reader. Each experiment was performed in triplicate.

\subsection{Statistical Analysis}

Data are expressed as mean \pm standard deviation (SD). Statistical evaluation was analyzed by one-way ANOVA using SPSS software (version 17.0, SPSS Inc., Chicago, USA). The value of $p<0.05$ between the treated groups and the control was considered to be statistically significant.

\section{Results and Discussion}

The previous studies demonstrated that there are multiple chemical constituents in C. nitidissima, including polyphenols [5], flavonoids [9,17], terpenes [10], saponins [11,18] and etc. Several investigations have shown that $C$. nitidissima leaves are rich in polyphenols [3,5] and flavonoids [14,19-21]. However, there is no literature to report the total content of saponins so far. To determine the total saponins content, a $0.5 \%$ anisaldehyde-sulphuric acid solution was used as a chromogenic agent, and oleanolic acid as a standard. In this work, the total saponins content exhibited distinct diversity that varied with the augment of leafage. The new $C$. nitidissima leaves possess the highest 
total saponins content $(6.21 \pm 0.15 \%)$, and the content is $1.98 \pm 0.12 \%$ and $2.15 \pm 0.18 \%$ for one and twoyear-old leaves, respectively. These results indicate that $C$. nitidissima leaves are rich in saponins.

\subsection{Chemistry}

There are twelve triterpenes and saponins were isolated from the leaves of $C$. nitidissima (Figure 1). NMR, IR, and MS techniques were used for the structure elucidation. By comparing the spectral data reported in works of literature, they were identified to be $\beta$-daucosterol (1)[22], $\alpha$-spinasterol $\beta$ -

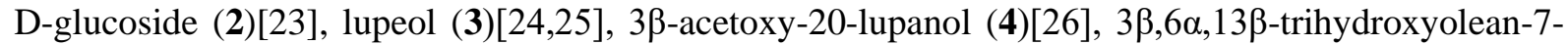
one (5)[27], oleanolic acid (6)[28], oleanolic acid 3-acetate (7)[29], ginsenoside $\operatorname{Rg}_{1}(8)$ [30], ginsenoside $F_{5}(\mathbf{9})\left[31\right.$ ], ginsenoside $F_{1}(\mathbf{1 0})[32]$, ginsenoside $R_{d}(11)[33$ ] and $(3 \beta, 6 \alpha, 12 \beta)-3,6,12-$ trihydroxydammar-24-en-20-yl-2-O- $\beta$-D-glucopyranosyl-(2 $\rightarrow 1)$-O- $\beta$-D-glucopyranosyl-( $2 \rightarrow 1)-\mathrm{O}-\alpha-$

L-Rhamnopyranoside (12). Especially, compound 12 is a new dammarane triterpenoid which has not been reported. It is worth noting that compounds 8-12 are five dammarane tetracyclic triterpenoids derived from 20(S)-protopanaxatriols, and they are firstly isolated from $C$. nitidissima plant.

Compound 12, obtained as white powder, the data of ${ }^{1} \mathrm{H}$ NMR $\left(600 \mathrm{MHz}\right.$, Pyridine- $\left.d_{5}\right)$ and ${ }^{13} \mathrm{C}$ NMR $\left(150 \mathrm{MHz}\right.$, Pyridine- $\left.d_{5}\right)$ listed in Table 1, negative HRESIMS: $\mathrm{m} / z$ 945.5423 [M-H] ${ }^{+}($calculated for $\mathrm{C}_{48} \mathrm{H}_{82} \mathrm{O}_{18}, 945.54284$, Figure 1S). The ${ }^{13} \mathrm{C}$ NMR and DEPT spectrum of compound 12 displayed forty-eight signals corresponding to nine methyls, ten methylenes, twenty-three methines and six quaternary carbon atoms. Acid hydrolysis produced two kinds of sugars, which were D-glucose and Lrhamnose identified by TLC analysis, and there are three anomeric proton at $\delta_{\mathrm{H}} 5.19 \mathrm{ppm}(1 \mathrm{H}, \mathrm{d}$, $J=7.9), 5.27 \mathrm{ppm}(1 \mathrm{H}, \mathrm{d}, J=7.6), 6.52 \mathrm{ppm}(1 \mathrm{H}, \mathrm{s})$, and $\delta \mathrm{c} 18.8 \mathrm{ppm}\left(\mathrm{CH}_{3}\right)$ of characteristic signal Lrhamnose. Then eighteen signals of ${ }^{13} \mathrm{C}$ NMR chemical shift were assigned to the sugar moieties, and thirty carbon signals were assigned to the aglycone part. Comparing the NMR data with literature[34,35], ginsenoside $\operatorname{Rg}_{1}(\mathbf{8})$ and ginsenoside $F_{5}(\mathbf{9})$, the downfield ${ }^{13} \mathrm{C}$ NMR chemical shift at $\delta_{\mathrm{C}} 83.3 \mathrm{ppm}(\mathrm{C}-20)$ suggested that compound $\mathbf{1 2}$ was a 20(S)-protopanaxatriol derivative with glycosidic linkages at C-20. The anomeric protons signals at $\delta_{\mathrm{H}} 5.19 \mathrm{ppm}(1 \mathrm{H}, \mathrm{d}, J=7.9$, Glc-1'), 5.27 ppm $\left(1 \mathrm{H}, \mathrm{d}, J=7.6\right.$, Glc-1"), $6.52 \mathrm{ppm}\left(1 \mathrm{H}, \mathrm{s}, \mathrm{Rha}-1 "{ }^{\prime \prime}\right)$ displayed correlations with anomeric carbon signals at $\delta_{\mathrm{C}} 98.3 \mathrm{ppm}, 101.9 \mathrm{ppm}$ and $\delta_{\mathrm{C}} 101.9 \mathrm{ppm}$ in HSQC, and showed correlations with $\delta_{\mathrm{C}} 83.3$ ppm (C-20), $75.2 \mathrm{ppm}$ (C-Glc-2'), $78.6 \mathrm{ppm}$ (C-Glc-2") in HMBC, respectively, indicating that the sequences of sugar residues were the Glc-1' link to C-20, Glc-1" link to C-Glc-2', and Rha-1"' link to C-Glc-2". The ${ }^{1} \mathrm{H}$ and ${ }^{13} \mathrm{C}$ NMR data of the monosaccharide residues were assigned starting from the readily identifiable anomeric protons by means of the HSQC, ${ }^{1}{ }^{1}-{ }^{1} \mathrm{H} C O S Y$, and HMBC spectra. The $\beta$-anomeric configurations of the D-glucoses were determined by $J_{\mathrm{H}^{\prime}, \mathrm{H} 2^{\prime}}$ and $J_{\mathrm{H} 1^{\prime \prime}, \mathrm{H} 2^{\prime \prime}}$ coupling constants at 7-8 Hz. The ${ }^{1} \mathrm{H}-{ }^{1} \mathrm{H}$ COSY and selected HMBC $(\mathrm{H} \rightarrow \mathrm{C})$ correlations are shown in Figure 2. To further confirm the structure of compound 12, the possible fragmentation pathway is presented in

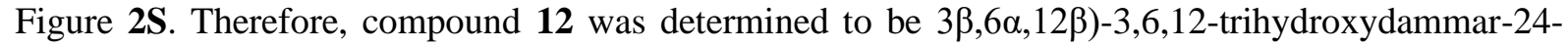
en-20-yl-2-O- $\beta$-D-glucopyranosyl-( $2 \rightarrow 1)$-O- $\beta$-D-glucopyranosyl- $(2 \rightarrow 1)$-O- $\alpha$-L-rhamnopyranoside.

\subsection{Cytotoxic Activity}

The invasion and metastasis of cancer are one of the main reasons that affect patients' health, even survival time. In the present study, the effects of the extracts and compound $\mathbf{1 2}$ from $C$. nitidissima leaves on Bel-7402 and SMMC-7721 cells migration were assayed using scratch wound assay at a concentration of $50 \mu \mathrm{g} / \mathrm{mL}$. As shown in Figure 3, compound 12 can effectively inhibit Bel7402 and SMMC-7721 cells migration when compared to the control. Inhibition of the extracts on Bel-7402 cells migration was also observed, but less influence on SMMC-7721 cells. Furthermore, the cytotoxic effects of the extract and compound 12 were evaluated against Bel-7402 and SMMC-7721 cells. After treatment of $24 \mathrm{~h}$ and $48 \mathrm{~h}$ with $12.5-200 \mu \mathrm{g} / \mathrm{mL}$ of samples, cell viabilities were measured by CCK-8 assay. As shown in Figure 4, the extract and compound $\mathbf{1 2}$ were found to exert proliferation inhibitory effects on two tumor cell lines in a dose-dependent manner. Compound $\mathbf{1 2}$ can reduce cell viability in Bel-7402 and SMMC-7721 cells, and the inhibitory rate of cell viability at $200 \mu \mathrm{g} / \mathrm{mL}$ reached about 30\% in Bel-7402 cells, and about 21\% in SMMC-7721 cells when treated $48 \mathrm{~h}$. The 


\section{Triterpenes and saponins from leaves of Camellia nitidissima}

extracts of $C$. nitidissima leaves also exhibited cytotoxic effect against Bel-7402 cells with an inhibitory rate of about $26 \%$ at $200 \mu \mathrm{g} / \mathrm{mL}$, but showed less inhibition effect on SMMC-7721 cells.<smiles>CCC(C)C(C)CCC(C)C1CCC2C3CCC4CC(OC5CCCCC5)CCC4(C)C3CCC12C</smiles>

1<smiles>CC(=O)OC1CCC2(C)C(CCCC23CCCC(C2C(C(C)(C)O)CCC2(C)C)C3C)C1(C)C</smiles>

4<smiles>CC(=O)OC1CCC2(C)C(CCC3C2CCC2CC(C)(C)CCC23C)CC1C</smiles>

7

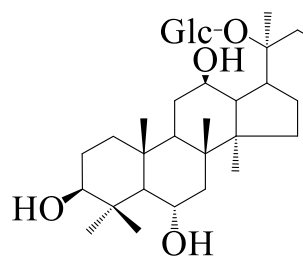

10<smiles>CCC(CC=CC(C)C1CCC2C3CCC4CC(CCC3C12C)OC1CCCCC1C4C)C(C)C</smiles>

2

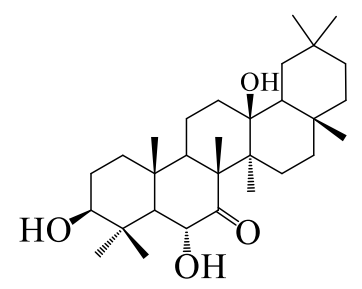

5
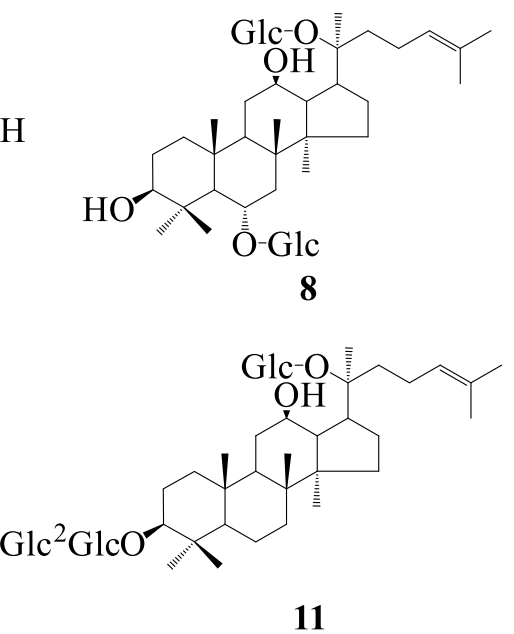<smiles>C=C(C)C1CCC2C1CCC1C2CCC2C1CCC1C2CCC1C(C)(C)O</smiles>

3<smiles>CC1(C)CCC2(C(=O)O)CCC34CCC5C(C)(C)C(O)CCC5(C)C3CCC4C2C1</smiles>

6

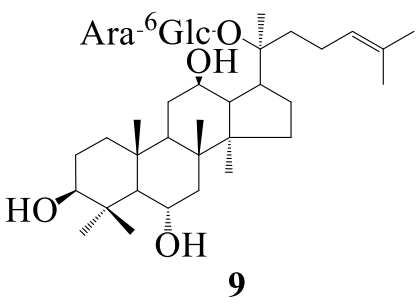

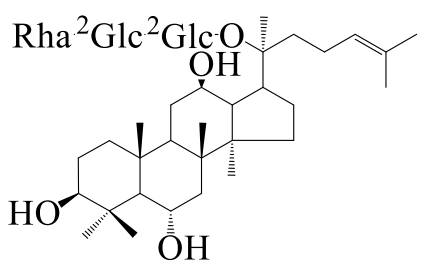

12

Figure 1. Chemical structures of compounds 1-12 isolated from C. nitidissima.

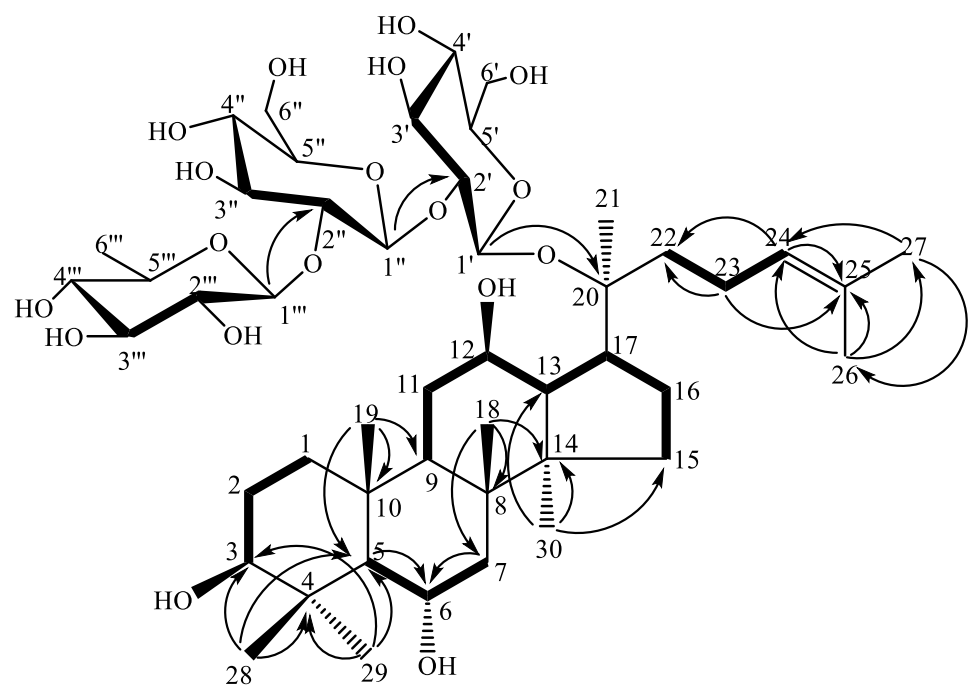

- COSY $\bigcirc \mathrm{HMBC}$

Figure 2. Key ${ }^{1} \mathrm{H}^{-1} \mathrm{H}$ COSY and $\mathrm{HMBC}$ correlations of compound $\mathbf{1 2}$

Table 1. ${ }^{1} \mathrm{H}$ and ${ }^{13} \mathrm{C}$ NMR data for compound 12 (at $600 \mathrm{MHz}$ in pyridine- $d_{5}, \delta$ in ppm, $J$ in $\mathrm{Hz}$ ) 
Xu et.al., Rec. Nat. Prod. (2022) 16:6 550-558

\begin{tabular}{|c|c|c|c|c|c|}
\hline $\begin{array}{l}\text { Aglycon Moiety } \\
\text { Position }\end{array}$ & $\begin{array}{c}\delta_{\mathrm{H}} \text { mult. } \\
(J \text { Hz })\end{array}$ & $\delta$ c mult. & $\begin{array}{l}\text { Sugar Moiety } \\
\text { Position }\end{array}$ & $\begin{array}{c}\delta_{\mathrm{H}} \text { mult. } \\
(J \text { Hz })\end{array}$ & $\delta$ c mult. \\
\hline 1 & $1.68 \mathrm{~m}, 0.92 \mathrm{~m}$ & $39.4 \mathrm{CH}_{2}$ & Glc-1' & $5.19 d(7.9)$ & $98.3 \mathrm{CH}$ \\
\hline 2 & $1.88 \mathrm{~m}, 1.69 \mathrm{~m}$ & $27.8 \mathrm{CH}_{2}$ & Glc-2' & $4.00^{b}$ & $75.2 \mathrm{CH}$ \\
\hline 3 & $3.49 \mathrm{~m}$-like & $78.4 \mathrm{CH}$ & Glc-3' & $4.20^{b}$ & $79.5 \mathrm{CH}$ \\
\hline 4 & & $40.0 \mathrm{C}$ & Glc-4' & $4.23 \mathrm{~m}$-like & $72.6 \mathrm{CH}$ \\
\hline 5 & $1.39 d(9.7)$ & $60.8 \mathrm{CH}$ & Glc-5' & $3.99 \mathrm{~m}$ & $78.4 \mathrm{CH}$ \\
\hline 6 & $4.70^{b}$ & $74.6 \mathrm{CH}$ & Glc-6' & $4.51^{b}, 4.36 \mathrm{~m}$ & $63.1 \mathrm{CH}_{2}$ \\
\hline 7 & $2.26 \mathrm{~m}, 1.97 \mathrm{~m}$ & $46.0 \mathrm{CH}_{2}$ & Glc-1" & $5.27 d(7.6)$ & $101.9 \mathrm{CH}$ \\
\hline 8 & & $41.2 \mathrm{C}$ & Glc-2" & $4.38^{b}$ & $78.6 \mathrm{CH}$ \\
\hline 9 & $1.52 \mathrm{~m}$ & $49.6 \mathrm{CH}$ & Glc-3" & $4.38^{b}$ & $79.3 \mathrm{CH}$ \\
\hline 10 & & $39.7 \mathrm{C}$ & Glc-4" & $4.18 \mathrm{~m}$ & $71.6 \mathrm{CH}$ \\
\hline 11 & $2.08 \mathrm{~m}, 1.48 \mathrm{~m}$ & $31.0 \mathrm{CH}_{2}$ & Glc-5" & $4.01 \mathrm{~m}$ & $78.3 \mathrm{CH}$ \\
\hline 12 & $4.18 \mathrm{~m}$ & $70.2 \mathrm{CH}$ & Glc-6" & $4.51^{b}, 4.36 \mathrm{~m}$ & $62.9 \mathrm{CH}_{2}$ \\
\hline 13 & $1.94 \mathrm{~m}$ & $49.1 \mathrm{CH}$ & Rha-1'" & $6.52 \mathrm{~s}$ & $101.9 \mathrm{CH}$ \\
\hline 14 & & $51.4 \mathrm{C}$ & Rha-2'" & $4.82 \mathrm{brs}$ & $72.4 \mathrm{CH}$ \\
\hline 15 & $2.07 \mathrm{~m}, 0.86 \mathrm{~m}$ & $30.7 \mathrm{CH}_{2}$ & Rha-3"' & $4.69 \mathrm{~m}$ & $72.3 \mathrm{CH}$ \\
\hline 16 & $1.80 \mathrm{~m}, 1.26 \mathrm{~m}$ & $26.7 \mathrm{CH}_{2}$ & Rha-4'" & $4.36^{b}$ & $74.2 \mathrm{CH}$ \\
\hline 17 & $2.50^{b}$ & $51.7 \mathrm{CH}$ & Rha-5'" & $4.97 d d(9.6,6.1)$ & $69.5 \mathrm{CH}$ \\
\hline 18 & $1.19 \mathrm{~s}$ & $17.8 \mathrm{CH}_{3}$ & Rha-6'" & $1.79 d(6.1)$ & $18.8 \mathrm{CH}_{3}$ \\
\hline 19 & $0.97 \mathrm{~s}$ & $17.5 \mathrm{CH}_{3}$ & 3'-OH & 7.48 brs & \\
\hline 20 & & $83.3 \mathrm{C}$ & 4'-OH & $6.63 \mathrm{~s}$ & \\
\hline 21 & $1.62 \mathrm{~s}$ & $22.3 \mathrm{CH}_{3}$ & 6'-OH & $6.16 \mathrm{~s}$ & \\
\hline 22 & $2.38 \mathrm{~m}, 1.77 \mathrm{~m}$ & $36.0 \mathrm{CH}_{2}$ & 3"-OH & $7.33 \mathrm{~s}$ & \\
\hline 23 & $2.49 \mathrm{~m}, 2.23 \mathrm{~m}$ & $23.2 \mathrm{CH}_{2}$ & 4"-OH & $7.27 \mathrm{~s}$ & \\
\hline 24 & $5.27^{b}$ & $126.0 \mathrm{CH}$ & 6"-OH & $6.06 \mathrm{~s}$ & \\
\hline 25 & & $130.9 \mathrm{C}$ & 2"'-OH & $7.19^{c}$ & \\
\hline 26 & $1.61 \mathrm{~s}$ & $25.8 \mathrm{CH}_{3}$ & 3"'-OH & $6.66 \mathrm{~s}$ & \\
\hline 27 & $1.64 \mathrm{~s}$ & $17.7 \mathrm{CH}_{3}$ & 4"'-OH & 7.43 brs & \\
\hline 28 & $2.12 \mathrm{~s}$ & $32.2 \mathrm{CH}_{3}$ & & & \\
\hline 29 & $1.37 \mathrm{~s}$ & $17.2 \mathrm{CH}_{3}$ & & & \\
\hline 30 & $0.95 \mathrm{~s}$ & $17.3 \mathrm{CH}_{3}$ & & & \\
\hline $3-\mathrm{OH}$ & $5.76 d(5.5)$ & & & & \\
\hline $6-\mathrm{OH}$ & $6.33 \mathrm{~s}$ & & & & \\
\hline $12-\mathrm{OH}$ & $5.60 \mathrm{~s}$ & & & & \\
\hline
\end{tabular}

${ }^{a}$ The assignments were based on DEPT, HSQC, ${ }^{1} \mathrm{H}-{ }^{1} \mathrm{H}$ COSY and HMBC experimental data.

${ }^{b}$ Overlapped with other signals.

${ }^{c}$ Overlapped with the solvent peak of pyridine- $d_{5}$. 
Triterpenes and saponins from leaves of Camellia nitidissima

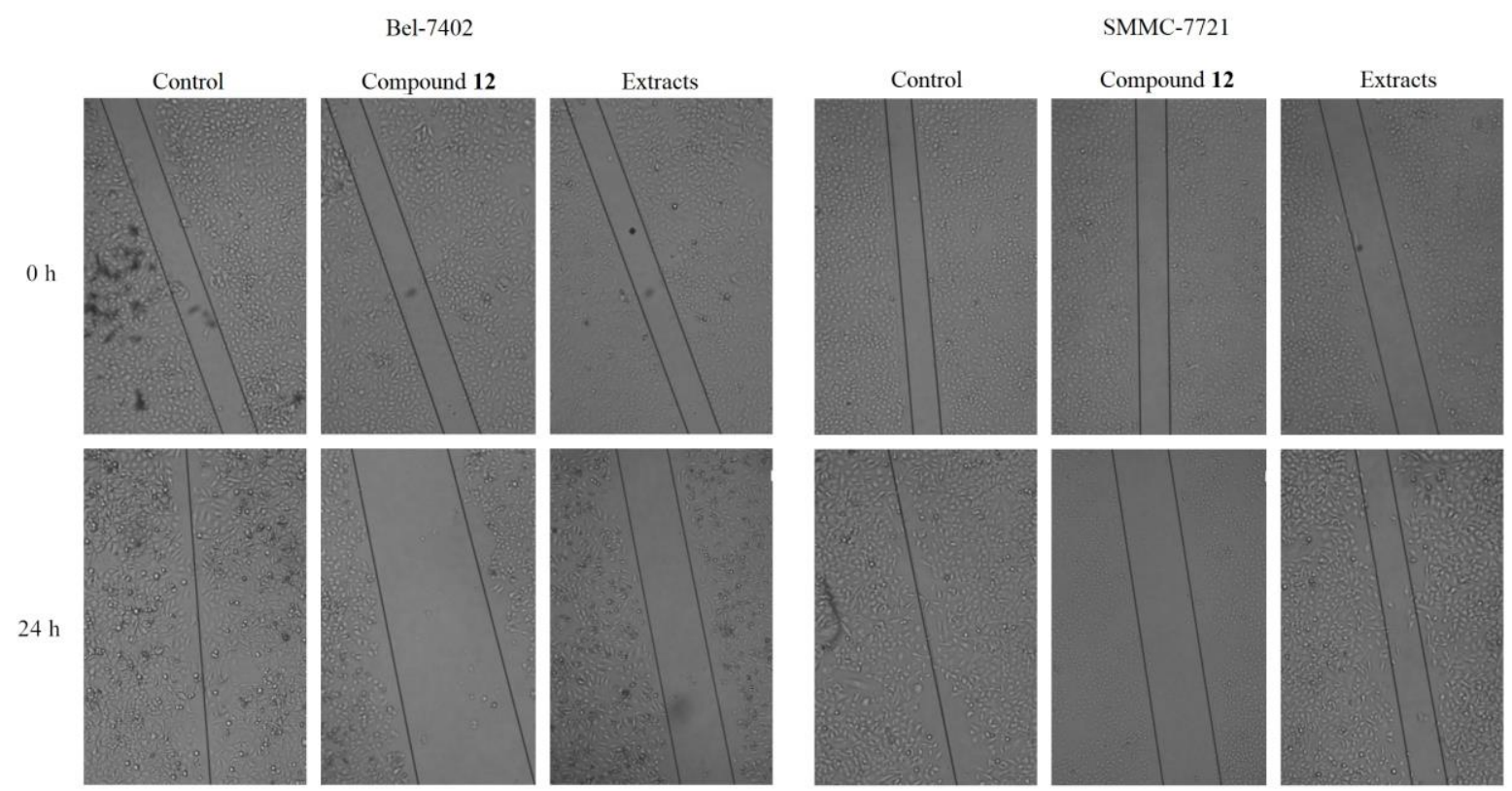

Figure 3. Micrographs of Bel-7402 and SMMC-7721 cells migration after treatment with $50 \mu \mathrm{g} / \mathrm{mL}$ extract and compound 12 for $0 \mathrm{~h}$ and $24 \mathrm{~h}$. Cells treated without any samples were used as the control.
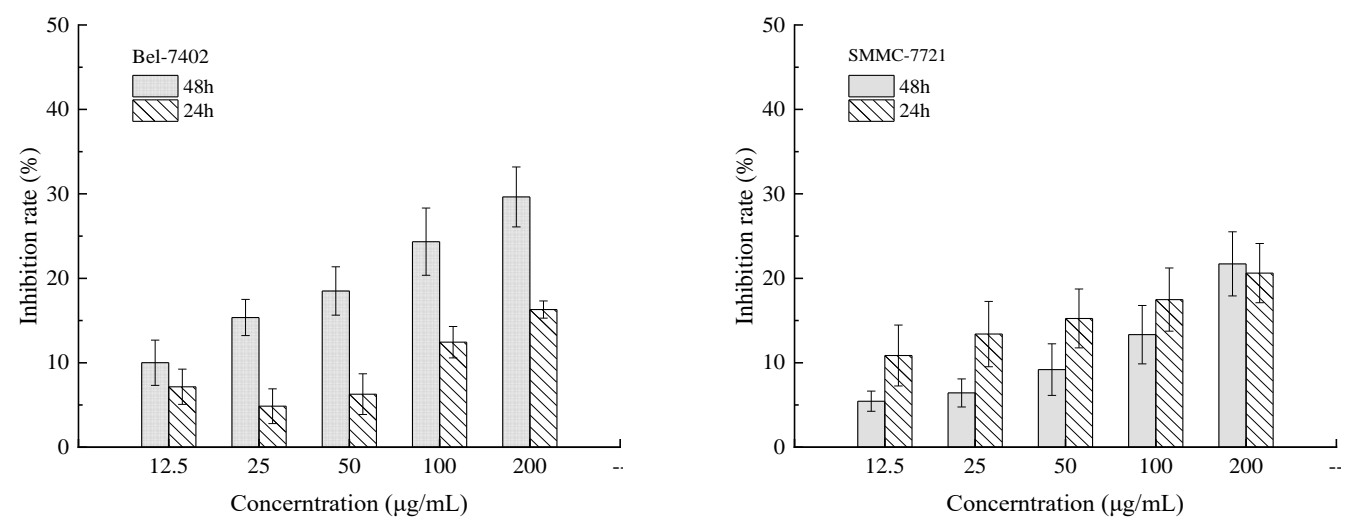

A
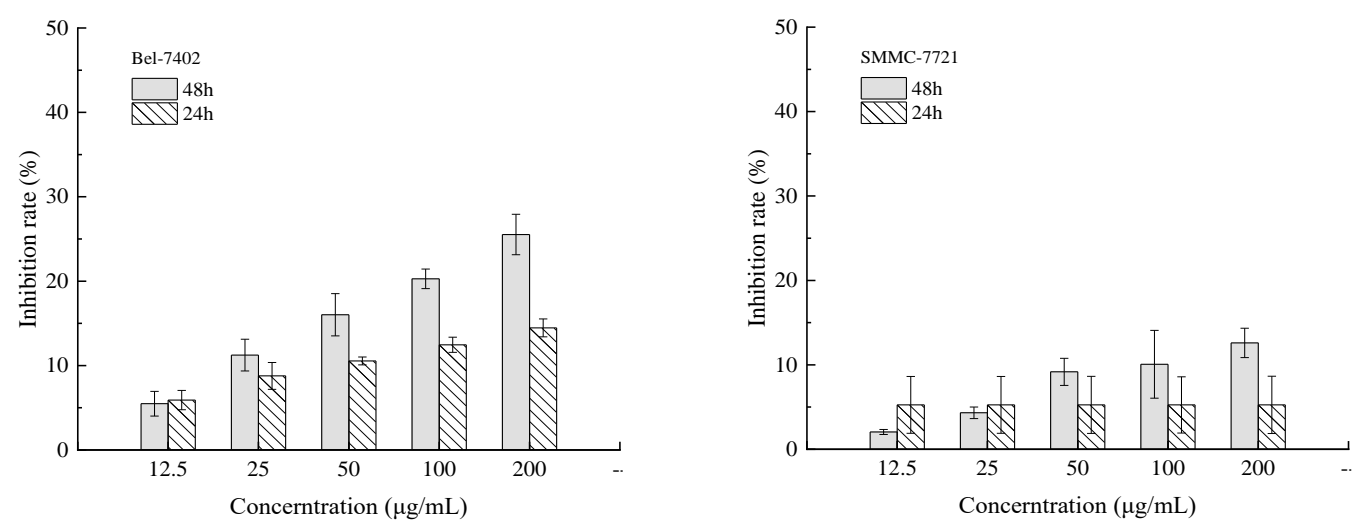

B

Figure 4. Proliferation inhibitory effect of the extracts (A) and compound 12 (B) obtained from $C$. nitidissima leaves on Bel-7402 and SMMC-7721 cells. 


\section{Acknowledgments}

This work was partially supported by the Project of Guangxi Fundamental Resources Platform of Science and Technology (No. 11-114-14B) and the Research Project of Guangxi Research Center of Analysis and Testing (No. 2019ACZ04).

\section{Supporting Information}

Supporting information accompanies this paper on http://www.acgpubs.org/journal/records-of$\underline{\text { natural-products }}$

\section{ORCID}

Yanan Xu: 0000-0002-2505-6583

Siyuan Ma: 0000-0002-6775-5892

Xiaofang Han: 0000-0003-3340-301X

Lin Su: 0000-0002-8714-8950

Li Ge: 0000-0002-2531-8897

Qiuhong Chen: 0000-0002-6763-3887

Kedi Yang: 0000-0002-2195-8782

Qifei Mo: $\underline{0000-0003-0642-7112}$

\section{References}

[1] L. An, W. Zhang, G.W. Ma, K. Wang, Y.F. Ji, H. Ren and Y.S. Wang (2020). Neuroprotective effects of Camellia nitidissima Chi leaf extract in hydrogen peroxide-treated human neuroblastoma cells and its molecule mechanisms, Food Sci. Nutr. 9, 4782-4793.

[2] X. He, H. Li, M.X. Zhan, H.Y. Li, A.Q. Jia, S.S. Lin, L. Sun, H.Z. Du, S.T. Yuan and Y. Li (2019). Camellia nitidissima Chi extract potentiates the sensitivity of gastric cancer cells to paclitaxel via the induction of autophagy and apoptosis, OncoTargets Ther. 12, 10811-10825.

[3] J.N. Lin, H.Y. Lin, N.S. Yang, Y.H. Li, M.R. Lee, C.H. Chuang, C.T. Ho, S.C. Kuo and T.D. Way (2013). Chemical constituents and anticancer activity of yellow camellias against MDA-MB-231 human breast cancer cells, J. Agric. Food Chem. 61, 9638-9644.

[4] J. Qi, R.F. Shi, J.M. Yu, Y. Li, S.T. Yuan, J.Z. Yang, J.M. Hu and A.Q. Jia (2016). Chemical constituents from leaves of Camellia nitidissima and their potential cytotoxicity on SGC7901 cells, Chinese Herbal Medicines 8, 80-84.

[5] L. Song, X. Wang, X. Zheng and D. Huang (2011). Polyphenolic antioxidant profiles of yellow camellia, Food Chem. 129, 351-357.

[6] J.B. Wei, X. Li, H. Song, Y.H. Liang, Y.Z. Pan, J.X. Ruan, X. Qin, Y.X. Chen, C.L. Nong and Z.H. Su (2015). Characterization and determination of antioxidant components in the leaves of Camellia chrysantha $(\mathrm{Hu})$ Tuyama based on composition-activity relationship approach, J. Food Drug Anal. 23, 40-48.

[7] W.X. Wang, H.Y. Liu, Z.N. Wang, J. Qi, S.T. Yuan, W.J. Zhang, H.J. Chen, J.W. Finley, L.W. Gu and A.Q. Jia. Phytochemicals from Camellia nitidissima Chi inhibited the formation of advanced glycation endproducts by scavenging methylglyoxal, Food Chem. 205, 204-211.

[8] H.L. Zhang, Q.X. Wu and X.M. Qin (2019). Camellia nitidissima Chi flower extracts inhibit $\alpha$-amylase and $\alpha$-glucosidase: In vitro by analysis of optimization of addition methods, inhibitory kinetics and mechanisms, Process Biochem, 86, 177-185.

[9] D.Y. He, X.Y. Li, X. Sai, L.L. Wang, S.Y. Li and Y.P. Xu (2018). Camellia nitidissima C.W. Chi: a review of botany, chemistry, and pharmacology, Phytochem. Rev. 17, 327-349.

[10] X.Y. Hou, H.Z. Du, R. Yang, J. Qi, Y. Huang, S.Y. Feng, Y. Wu, S.S. Lin, Z.X. Liu, A.Q. Jia, S.T. Yuan and L. Sun (2018). The antitumor activity screening of chemical constituents from Camellia nitidissima Chi, Int. J. Mol. Med. 41, 2793-2801.

[11] L. Su, J.G. Mo, Y.L. Wei, Q.H. Chen and Y.K. Pan (2012). Chemical constituents of saponins from leaves of Camellia euphlebia, Chinese Traditional and Herbal Drugs 43, 877-879.

[12] D.M. Tran, T.T. Nguyen, T.S. Hoang, V.T. Dang, T.P. Dinh, T. Nguyen, T.D. Dao, T.L. Mai, T.L. Vu, H.T. Nguyen, T.T.P. Nguyen and T.V. Do (2019). Golden Camellias: A Review, Archives of Current Research International, 1-8. 


\section{Triterpenes and saponins from leaves of Camellia nitidissima}

[13] B. Wang, L. Ge, J.G. Mo, L. Su, Y.J. Li and K.D. Yang (2018). Essential oils and ethanol extract from Camellia nitidissima and evaluation of their biological activity, J. Food Sci. Tech. Mys. 55, 5075-5081.

[14] Z.N. Wang, B. Sun, R. Yang and A.Q. Jia (2021). Flavonoids and other phenolics from Camellia nitidissima chi flowers, Nat. Pro. Res. 1-8.

[15] J. Baccou, F. Lambert and Y. Sauvaire (1977). Spectrophotometric method for the determination of total steroidal sapogenin, Analyst 102, 458-465.

[16] C.C. Liang, A.Y. Park and J.L. Guan (2007). In vitro scratch assay: a convenient and inexpensive method for analysis of cell migration in vitro, Nat. Protoc. 2, 329.

[17] D.F. Zou, W. Zhang, C.Y. Liang, X.W. Zhang and L.D. Huang (2015). HPLC fingerprint of flavonoids from Camellia chrysantha leaves, West China J.Pharmaceut. Sci. 30, 462-464.

[18] P. Xiao, D.Y. Yu, B.M. Feng, L. Tang, Y.Q. Wang and L.Y. Shi (2011). Chemical constituents from the flowers of Camellia chrysantha, Guihaia 31, 550-553+568.

[19] Y.L. Huang, Y.X. Wen, Y.Y. Chen, W.X. Tang, D.P. Li, J.L. Liu and X. Wei (2009). Study on the extraction technology and dynamic change of flavonoids in Camellia nitidssima leaves, Food Science 30, $72-75$.

[20] Y.L. Huang, Y.X. Wen, J.L. Liu, D.P. Li, H.R. Zhang and X. Wei (2009). Deteminition of total flavonoids content in five yellow Camellia plants, Chinese Journal of Traditional Medical Science and Technology 16, 38-39.

[21] X.X. Huang, R. Zou, X.H. Hu, X. Wei, H. Tang and X.X. Qi (2011). Comparison of total flavonoids content in 14 species of Camellia sect. Chrysantha, Guihaia 31, 281-284.

[22] L.R. Chadwick, D. Nikolic, J.E. Burdette, C.R. Overk and G.F. Pauli (2004). Estrogens and congeners from Spent Hops (Humulus lupulus), J. Nat. Prod. 67, 2024-2032.

[23] Y. Jiang, L. Liu and P.F. Tu (2003). Study on chemical constituents of Polygala tenuifolia III, Chin. J. Nat. Med. 1, 142-145.

[24] J. Wei, X.S. Yang, H.Y. Zhu and X.J. Hao (2008). Chemical constituents of Vaccinium carlesii, Guihaia. 28, 558-560.

[25] J. Fotie, D.S. Bohle, M.L. Leimanis, E. Georges, G. Rukunga and A.E. Nkengfack (2006). Lupeol longchain fatty acid esters with antimalarial activity from Holarrhena floribunda, J. Nat. Prod. 69, 62-67.

[26] J. Li, Q.S. Song, W. Xiang and S.M. Yang (2009). Chemical studies on Ophiorrhiza grandibracteolata, Nat. Prod. Res. Dev. 21, 433-434.

[27] T.J. Ling, X.C. Wan, W.W. Ling, Z.Z. Zhang, T. Xia, D.X. Li and R.N. Hou (2010). New triterpenoids and other constituents from a special microbial-fermented tea-Fuzhuan brick tea, J. Agric. Food Chem. 58, 4945-4950.

[28] W. Seebacher, N. Simic, R. Weis, R. Saf and O. Kunert (2003). Complete assignments of ${ }^{1} \mathrm{H}$ and ${ }^{13} \mathrm{C}$ NMR resonances of oleanolic acid, 18 $\alpha$-oleanolic acid, ursolic acid and their 11-oxo derivatives, Magn. Reson. Chem. 41, 636-638.

[29] J.C. Lu, B.B. Xu, X.Y. Zhang and Q.S. Sun (2002). Study on chemical constituents of rhizome of Anemone Raddeana, Acta Pharm. Sin. 37, 709-712.

[30] R.W. Teng, H.Z. Li, J.T. Chen, D.Z. Wang, Y.N. He and C.R. Yang (2002). Complete assignment of ${ }^{1} \mathrm{H}$ and ${ }^{13} \mathrm{C}$ NMR data for nine protopanaxatriol glycosides, Magn. Reson. Chem. 40, 483-488.

[31] D.Q. Dou, Y.J. Chen, Z.R. Ma, Y. Wen, M.H. Wang, Y.P. Pei, Z.X. Wang, H. Kawai, H. Fukushima and Y. Murakami (1996). A novel minor saponin from the leaves of Panax Ginseng. C. A. Meyer, J. Chin. Pharm. Sci. 5, 48-52.

[32] S.R. Ko, K.J. Choi, K. Suzuki and Y. Suzuki (2003). Enzymatic preparation of ginsenosides $\operatorname{Rg}_{2}, \mathrm{Rh}_{1}$, and $\mathrm{F}_{1}$. Chem Pharm. Bull. 51, 404-408.

[33] J. Lei, X. Li, X.J. Gong and Y.N. Zheng (2007). Isolation, Synthesis and Structures of Cytotoxic Ginsenoside Derivatives, Molecules 12, 2140-2150.

[34] D. Dou, Y. Wen, Y. Pei, X. Yao, Y. Chen, H. Kawai and H. Fukushima (1996). Ginsenoside- $\mathrm{I}_{\mathrm{a}}$ : A Novel minor saponin from the leaves of Panax ginseng, Planta Med. 6, 179-181.

[35] Y. Usami, Y.N. Liu, A.S. Lin, M. Shibano, T. Akiyama, H. Itokawa, S.L. Morris-Natschke, K. Bastow, R.Kasai and K.H. Lee (2008). Antitumor agents. 261. 20(S)-Protopanaxadiol and 20(S)-Protopanaxatriol as antiangiogenic agents and total assignment of ${ }^{1} \mathrm{H}$ NMR spectra, J. Nat. Prod. 71, 478-481

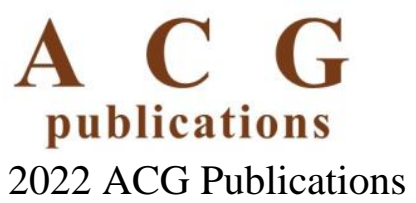

